\title{
Fagfornyelsen i KRLE og Religion og etikk:
}

\section{Etter laereplanen - for implementeringen}

Av GeIR SKeIE, professor $i$ religionsdidaktikk ved UiS, leder av arbeidsgruppa som Utdanningsdirektoratet brukte for å utarbeide forslag til nye loereplaner $i$ KRLE/RE 2017--2019.

E-post:geir.skeie@uis.no

Etter å ha vært sterkt involvert i prosessen fram mot ny læreplan i KRLE og Religion og etikk, er det på mange måter krevende å skifte perspektiv fra å se det hele «innenfra» til å se det «utenfra». Som religionsdidaktisk forsker har jeg hele tida i læreplanprosessen hatt med meg en selvrefleksjon, men samtidig er det begrenset hva man kan bruke det til, når plan skal skrives. Sentrale premisser for læreplanen var som vanlig lagt på forhånd gjennom utredninger og politiske føringer (Kunnskapsdepartementet, 2016; NOU 2014:7, 2014; NOU 2015:8, 2015). Det viktigste for vårt arbeid var etter min mening etableringen av de knappe formuleringer som definerte kjerneelementer i fagene i en første runde. Jeg ledet også dette arbeidet, og erfarte hvor krevende og samtidig konsekvensrikt dette ble. I neste runde skulle jo kjerneelementene styre skriving av forslag til læreplaner med den uttrykte intensjon at disse skulle bli vesentlig mindre omfattende og detaljerte enn de som hadde vært tidligere.

I tillegg var vedtak gjort om ny overordnet del (Kunnskapsdepartementet, 2017). Her var blant annet de tverrfaglige temaene definert, og de skulle sammen med andre verdier og prinsipper innlemmes i læreplaner for fag etter beste skjønn. Min oppfatning er likevel at dette var en mindre viktig enkeltfaktor når det gjaldt utforming av de nye læreplanene enn kjerneelementene, hvis vi spør etter hva som bidro mest til endring i fagenes innhold. Da vi arbeidet med kjerneelementene, var ikke dette kombinert med en skisse til fagplan. De to prosessene ble dermed på sett og vis atskilt. Dette var antakelig noe av hensikten, for å sikre effekten av å etablere kjerneelementer som en premiss for selve fagplanen. Det førte muligens til at det ble enklere å foreslå kjerneelementer som ikke hadde samme kunnskapsmessige status. Når man ser formuleringene, er det slående at særlig det første kjerneelementet «Kjennskap til religioner og livssyn» omfatter et svært bredt kunnskapsområde fra vitenskapsfagene. Noe tilsvarende kan sies om «Utforsking av religioner og livssyn med ulike metoder». Derimot har de to neste en helt annen karakter, «Utforsking av eksistensielle spørsmål og svar» og «Kunne ta andres perspektiv» kan begge oppfattes som tematiske eller prosessuelle med noe mindre direkte forankring i vitenskapsfagene. Det siste, «Etisk refleksjon» fanger 
inn etikk som kunnskapsfelt, med en viss vekt på det resonnerende og analytiske.

Til sammen innebar dette at fagplanarbeidet måtte gjøre en rekke valg når det gjaldt en operasjonalisering av disse kjerneelementene i form av kompetansemål. Selv om vi møtte en rekke kritiske kommentarer til de fem kjerneelementene, ble det mye klarere da de første skissene til læreplan ble lagt ut, at mange var skeptiske. Dette gikk dels på konkrete faglige elementer som var svakere representert i forslagene enn i tidligere fagplaner. Her er nok det historiske perspektivet det klareste eksempel. Fagplangruppa gjorde et valg om å primært legge vekt på samtidsreligion og livssyn i dag, og å tone ned det historiske, kronologisk forstått. Det var derfor interessant å møte den tolkning som Tarald Rasmussen lanserer med vekt på bruken av ordet «tradisjon» i læreplanen, at dette signaliserte et historisk perspektiv (se s. 325). Selv om dette ikke var intensjonen i fagplangruppa, er det på sett og vis $\mathrm{i}$ tråd med vårt perspektiv: å forholde seg til historien gjennom samtiden heller enn motsatt.

Den andre typen kritikk av læreplanen har hele tiden vært at den er for åpen, vag og upresis når det gjelder faglig innhold, altså hvilke konkrete elementer fra religionsfagenes kunnskapsområder som skal vektlegges. Mange har kommentert at dette fører til altfor store utfordringer for lærerne når det gjelder å velge innhold i undervisningen, og altfor store ulikheter mellom skoler og klasser lokalt og nasjonalt. I forlengelsen av dette har det vært hevdet at resultatet kan bli en økende avhengighet av læremidlene, altså at lærerne overlater innholdsvalgene til læreboka, stikk i strid med det som er intensjonen med reformen. Hele tida har andre lesere av planen hatt motsatte oppfatninger, altså at planens åpenhet gir lærerne en ønsket faglig frihet, at man må forutsette faglig og fagdidaktisk dyktige lærere som klarer å gjøre slike valg og at ulikheter mellom klasser og skoler kan kompenseres gjennom bruk av nye eksamensformer.

Selv om jeg ikke mener disse innvendingene er avgjørende, har både fagplangruppas diskusjoner underveis og min egen refleksjon i ettertid overbevist meg om at de er viktige og dermed kritiske for læreplanreformens skjebne. Det er etter min mening naivt å tro at en læreplanreform skal endre skolen til det bedre uten risiko for å mislykkes. En rekke faktorer er viktige for å bidra til positiv endring, og mye avhenger av hvordan implementering gjennomføres, både med blikk for oppgavens kompleksitet og for det omfattende samvirke som må til (Burner, 2018). På et mer overordnet nivå vil det også være slik at parallelle utdanningspolitiske beslutninger kan komme til å avgjøre noe av reformens skjebne. Ideene om dybdelæring, et bredt kompetansebegrep og danning for å møte framtidas utfordringer skal brynes mot mer håndfaste planer om kontroll med ressursbruk, prestasjonsmål i internasjonale tester og målstyring mer generelt. Hvordan spenningen mellom de nevnte «ideene» og «planene» tar form og avstemmes i den enkelte skole og dens klasserom, kan bli det som avgjør fagfornyelsens skjebne. La 
meg derfor peke på tre muligheter som lærere og lærerutdannere innenfor KRLE og Religion og etikk står overfor nå når innføring av fagfornyelsen har begynt og utfordringene melder seg.

Det første handler om ideene knytta til dybdelæring og de forestillinger om forholdet mellom vitenskapsfag og skolefag som ligger implisitt i dette. Min oppfatning er at innholdet i dybdelæring og hvordan det skal realiseres didaktisk, ikke er tilstrekkelig klart, og at et videre arbeid med dette kan bidra til å utvikle innholdet $\mathrm{i}$ de to første kjerneelementene. Her finnes muligheter for at lærere og lærerutdannere både hver for seg og i samarbeid kan utvikle kunnskap om hva «utforsking» kan bety i religions- og livssynsfag. Elever i grunnskolen skal ikke bli «små religionsforskere», men det forhindrer ikke at de kan leke at de forsker på religion, og at leken kan gi kunnskap gjennom allsidig bearbeiding av innsamlet materiale med bruk av faglige innfallsvinkler, grunnleggende ferdigheter og kritisk tenkning. På videregående kan det være mulig å prøve ut forskerrollen litt mer seriøst, i tråd med det studieforberedende siktet. Et eksempel på slik begynnende utprøving av muligheter finnes ved Charlottenlund ungdomsskole i Trondheim (Wendel \& Mongstad, 2019, 2020), inspirert av ideer fra England (G. Freathy, Freathy, Doney, Walshe, \& Teece, 2015; R. Freathy \& John, 2018).

Det andre dreier seg om hvordan de kjente formuleringene fra opplæringslova om at kristendom, andre verdensreligioner og livssyn skal presenteres på en «objektiv, kritisk og pluralistisk måte» skal balanseres i forhold til at fagfornyelsen legger vekt på «utforsking av eksistensielle spørsmål og svar» og å «kunne ta andres perspektiv». Fra svensk religionsundervisnings historie vet vi at innføringen av «objektiv» religionsundervisning i sin tid førte til det Sven Hartman og andre har kalt en «objektivitetskrampe» hos mange lærere, som gikk ut over undervisningens kvalitet (Hartman, 2000). Nyere svensk forskning har funnet at klasserommet noen steder preges av en hegemonisk diskurs som hindrer elever i å ta ordet og dermed gjør det vanskelig å «ta andres perspektiv», og som reiser spørsmålet om hvordan og på hvilke måter religionsundervisningen skal være «trygg» (Flensner \& Lippe, 2019; C. Osbeck \& Lied, 2012; Christina Osbeck, Sporre, \& Skeie, 2017). Det er en spennende og krevende utfordring for lærere og elever å fylle disse kjerneelementene med innhold, og det krever en fornyet beskjeftigelse med hva som ligger i eksistensielle spørsmål og svar ut over det som er etablert kunnskap om religions- og livssynstradisjoner. En mulighet er å gjøre bruk av nyere religionsforsknings interesse for «levd religion», for eksempel slik Therese Britton har gjort i forbindelse med ekskursjoner (Britton, 2019). «Levd religion» fanger opp hvordan individers eksistensielle spørsmål preges av både deres egen historie og identitet og hva slags livssituasjon og kontekst de befinner seg i (Zetterqvist, 2009).

Det tredje jeg vil peke på, representerer betydningen av å ha et kritisk 
perspektiv på de nye læreplanene basert på en analyse av hva som kjennetegner de policy-tendenser som planene langt på vei bygger på. Det kompetansebegrep som brukes, er langt på vei hentet fra OECD og andre internasjonale utdanningspolitiske aktører og legger vekt på begreper som selvregulering, metakognisjon og forberedelse for et arbeidsliv der man skal arbeide i heterogene grupper med problemstillinger som ikke er kjente fra før (Kunnskapsdepartementet, 2016, s. 28 og 41). Dette fanger opp viktige samfunnsmessige utfordringer, men det preges samtidig av ønsket om en fleksibel og individuelt tilpasset arbeidsstyrke som er klar for et arbeidsmarked preget av endringer. Det kan synes å innebære et middelklasseperspektiv med konkurranseorientering og individualisme, som i skolen tar form av ansvar for egen læring, individuelle læringsplaner og læringsstrategier etc., og som godt kan kombineres med målbare resultater (Biesta, 2010). Til gjengjeld kan andre verdier komme til kort, slik som mer kollektive og gruppeorienterte perspektiv med vekt på deltakelse og inkludering av alle elever, ulike aktiviteter som er her-og-nå-orienterte, møtet med det Andre og ukjente, estetiske og kroppslige perspektiv (Østern et al., 2019). Mitt poeng er at Fagfornyelsen gir en frihet til lærere og elever, og vi vet enda ikke hva den blir tatt i bruk til, verken fra myndighetenes side eller fra skolenes. Det er ikke bare tale om «metodefrihet», men et stykke på vei også innholdsfrihet. Med frihet følger stort ansvar. Den vekt på lærerarbeidet som enkelte pedagoger har ønsket for å balansere det tidligere så ensidige læringsfokus (Biesta, 2015, 2017), kan nå bli realitet, men krever kritisk tenkning og klok handling.

\section{LITTERATUR}

Biesta, G. (2010). Good education in an age of measurement. Ethics, politics, democracy. Boulder, Colo: Paradigm Publishers.

Biesta, G. (2015). «Freeing Teaching from Learning. Opening Up Existential

Possibilities in Educational Relationships.» An International Journal, 34(3), 229-243. doi:10.1007/s11217-014-9454-z

Biesta, G. (2017). The Rediscovery of Teaching. New York: Routledge.

Britton, T. (2019). Att möta det levda. Möjligheter och hinder för förstå else av levd religion $i$ en studiebesöksorienterad religionskunskapsundervisning ( $\mathrm{PhD}$ avh). Stockholm: Stockholms universitet.

Burner, T. (2018). «Why is educational change so difficult and how can we make it more effective?» Forskning \& Forandring, 1(1), 122-134. doi:10.23865/fof. v1.1081

Flensner, K. K., \& Lippe, M. v. d. (2019). «Being safe from what and safe for whom? A critical discussion of the conceptual metaphor of 'safe space'.» Intercultural Education, 30(3), 275-288.

Freathy, G., Freathy, R., Doney, J., Walshe, K., \& Teece, G. (2015). The 
RE-searchers. A New Approach to Religious Education in Primary Schools. Exeter: The University of Exeter.

Freathy, R., \& John, H. C. (2018). «Religious Education, Big Ideas and the study of religion(s) and worldview(s).» British Journal of Religious Education, 41(1), $27-40$.

Hartman, S. G. (2000). «Hur religionsämnet formades.» I E. Almén, R. Furenhed, S. G. Hartman, \& B. Skogar (red.), Livstolkning och värdegrund. Att undervisa om religion, livsfrågor och etik (s. 212-251). Linköping: Linköpings universitet.

Kunnskapsdepartementet. (2016). Meld. St. 28 (2015-2016) Fag - Fordypning Forståelse. En fornyelse av Kunnskapsløftet. Hentet fra https://www.regjeringen. no/contentassets/e 8e1f41732ca4a64b003fca213ae663b/no/pdfs/ stm201520160028000dddpdfs.pdf

Kunnskapsdepartementet. (2017). Læreplanverket - overordnet del. Oslo: Utdanningsdirektoratet.

NOU 2014:7. (2014). Elevenes læring i fremtidens skole. Et kunnskapsgrunnlag. Hentet fra https://www.regjeringen.no/contentassets/e22a715fa374474581a8c58288edc161/no/pdfs/nou201420140007000dddpdfs.pdf

NOU 2015:8. (2015). Fremtidens skole. Fornyelse av fag og kompetanser. Hentet fra https://www.regjeringen.no/contentassets/da148fec8c4a4ab88daa8b677a700292/no/pdfs/nou201520150008000dddpdfs.pdf

Osbeck, C., \& Lied, S. (2012). «Hegemonic speech genres of classrooms and their importance for RE learning.» British Journal of Religious Education, 34(2), 155-168. doi:10.1080/01416200.2011.628194

Osbeck, C., Sporre, K., \& Skeie, G. (2017). «The RE classroom as a safe Public Space. Critical perspctives in dialogue, demands for respect and nuanced religous education.» I M. Rothgangel, K. v. Brömssen, H.-G. Heimbrock, \& G. Skeie (red.), Location, Space and Place in Religious Education (s. 49-66). Münster: Waxmann Verlag.

Wendel, G., \& Mongstad, B. (2019). «Dybde i læring - MOVe i skolen.» Religion og livssyn. Tidsskrift for Religionslærerforeningen i Norge, 31, 16-20.

Wendel, G., \& Mongstad, B. (2020). «To lærere laget nytt fag av KRLE og samfunnsfag. Menneske og Verden.» Utdanningsnytt.

Zetterqvist, K. G. (2009). «En vidlyftig begreppsflora? Närläsning av en sjuttiotalsdialog.» I K. G. Zetterqvist, G. J. Gunnarsson, \& S. G. Hartman (red.), Livet tillfrågas. Teoretiska förutsättningar för en livsfrågeorienterad religionsundervisning (s. 7-36). Stockholm: Stockholms universitet.

Østern, T. P., Dahl, T., Strømme, A., Aagaard Petersen , J., Østern, A.-L., \& Selander, S. (red.). (2019). Dybdelaring. En flerfaglig, relasjonell og skapende tilnærming. Oslo: Universitetsforlaget. 